\title{
Promoting Youth Entrepreneurship and Employability through Non-Formal and Informal Learning: The Latvia Case
}

Tamara Pigozne ${ }^{1}$, Ineta Luka ${ }^{2}$ and Svetlana Surikova*3

$\approx$ This paper presents some results of the research on 'Adult education resources to reduce youth unemployment', which is a part of the project 'Implementation of the European agenda for adult learning. The research applies a mixed-method approach (quantitative and qualitative data analysis). The purpose of the paper is to identify the most/leastefficient non-formal and informal learning methods, forms, and initiatives to promote youth entrepreneurship and employability in Latvia as well as to show the relationship between the profile of young adults and their opinion on these methods, forms, and initiatives. The findings show that the young adults stressed the importance of cooperation with employers in organising educational activities, field trips as well as the necessity of having internships, projects, and meetings with entrepreneurs to learn from their experience. The most efficient non-formal and informal learning methods, forms, and initiatives to promote youth entrepreneurship and employability in Latvia are as follows: internship in a company or institution, projects, other persons' experience and success stories, and training enterprises. The least efficient ones are mentoring, business incubators, coaching, individual work/action plan for the young people, business clubs, and business start-up funds/grants. The opinion of young adults on all aspects of non-formal and informal learning methods, forms, and initiatives depends on their profile (gender, education level, employment status, learning experience, etc.).

Keywords: employability, informal learning, Latvia, non-formal learning, youth entrepreneurship, youth unemployment 


\section{Spodbujanje mladinskega podjetništva in zaposljivosti z neformalnim in s priložnostnim učenjem: primer Latvije}

Tamara Pigozne, Ineta Luka in Svetlana Surikova

$\curvearrowright$ V prispevku so predstavljeni nekateri izsledki raziskave z naslovom Viri izobraževanja odraslih za zmanjšanje brezposelnosti mladih, ki je del projekta Izvajanje evropske agende za izobraževanje odraslih. Raziskava uporablja pristop mešanih metod (kvantitativna in kvalitativna analiza podatkov). Namen članka je opredeliti najučinkovitejše/najmanj učinkovite metode, oblike in pobude za neformalno in priložnostno učenje $\mathrm{z}$ namenom spodbujanja podjetništva in zaposljivosti mladih $\mathrm{v}$ Latviji ter prikazati odnos med profilom mladih odraslih in njihovim mnenjem o teh metodah, oblikah in o pobudah. Ugotovitve kažejo, da so mladi poudarili pomembnost sodelovanja $z$ delodajalci pri organizaciji izobraževalnih dejavnosti, ekskurzije ter potrebo po pripravništvu, projektih in po srečanjih s podjetniki z namenom učenja iz njihovih izkušenj. Najučinkovitejše neformalne in priložnostne učne metode, oblike in pobude za spodbujanje podjetništva in zaposljivosti mladih v Latviji so: pripravništvo v podjetju ali ustanovi, projekti, izkušnje drugih in uspešne zgodbe ter usposabljanje podjetij. Najmanj učinkoviti so: mentorstvo, poslovni inkubatorji, »coaching «, individualno delo/akcijski načrt za mlade, poslovni klubi in zagonski kapital/sredstva za ustanovitev podjetja. Mnenje mladih o vseh vidikih, oblikah in o pobudah neformalnega in priložnostnega učenja je odvisno od njihovega profila (spol, stopnja izobrazbe, zaposlitveni status, učne izkušnje itn.).

Ključne besede: zaposljivost, priložnostno učenje, Latvija, neformalno učenje, podjetništvo mladih, brezposelnost mladih 


\section{Introduction}

The twenty-first century has brought many challenges for people in all spheres and also impacted their employability, personal fulfilment, and well-being. In this context, the role of learning increases but approaches to learning are changing. Adult learning remains a topic of great interest in Europe (Cedefop, 2015; EAEA, 2014; European Commission/EACEA/Eurydice, 2015; UNESCO, 2016a). The Electronic Platform for Adult Learning in Europe (EPALE) funded by the European Commission is one of the latest developments in an ongoing commitment to improving the quality of the provision of adult learning in Europe. However, despite various improvements, adult learning in Europe still needs to become more flexible, accessible, inclusive and, attractive (Cedefop, 2015). According to Falasca (2011, p. 583), 'a fundamental aspect of adult education is engaging adults in becoming lifelong learners'. Criu and Ceobanu (2013) indicated four approaches for analysing adult education: 1) as practical training for an individual's career and professional life; 2 ) as an activity meant to enhance the quality of life; 3 ) as a form of democratic activity; and 4) as a form of social action. Considering these approaches, the current research encompasses the first two of them. This is in line with the general understanding of adult education in the country. In Latvia, adult education is perceived as a diverse process offering personal development and the capacity to cope in the labour market throughout life and its primary challenge is how to increase the participation rate in adult learning. Therefore, the enhancement of the second chance education opportunities, especially for social risk groups is recognised as a priority in adult education policy (EAEA, 2011). This premise is supported by the concept of lifelong learning, and in the context of Latvia, it specifically emphasises the role of continuing training and professional development mentioned in the Recommendation on Adult Learning and Education 2015 (UNESCO, 2016b).

Buchert (2014, p. 174) stressed that '...education has a critical role to play for the life chances of youth and their inclusion in or exclusion from social opportunities. The issue of learning outcomes is therefore central to policy discussions nationally and internationally'. It should be specified that for the purpose of this paper the understanding of youth (Buchert, 2014) or young people (Hoskins, Janmaat, \& Villalba, 2012; Murray \& Mitchell, 2013) or young adults (Criu \& Ceobanu, 2013; Knipprath \& De Rick, 2014; Murray \& Mitchell, 2013) or younger adults (Jordan, Carlile, \& Stack, 2008) refers to the individual's development stage between adolescence and maturity (adulthood). Therefore, youth learning is understood as a part of adult learning, and it is defined as an early stage of adult learning. 
The research on promoting youth entrepreneurship and employability through non-formal and informal learning is a small part of the study on adult learning conducted within the project 'Implementation of the European agenda for adult learning' (managed by the Ministry of Education and Science of the Republic of Latvia (MoES) and funded by EC, 2012-2014, grant decision No 20123753/o01-001) aimed at promoting collaboration and creating a network between all stakeholders involved in adult learning to enhance adults' skills, competencies and raise their qualification. The project covers five areas. This paper deals with the analysis of some findings on youth learning discovered in Part 2 'Adult education resources to diminish youth unemployment' (Pīgozne, 2014).

The focus of the current paper is on researching the various means of promoting youth entrepreneurship in Latvia and identifying the most/leastefficient ones in the context of adult learning.

\section{Theoretical Background}

\section{Terminology Issues}

The National Research and Development Centre for Adult Literacy and Numeracy (NRDC) has conducted a study for the European Commission on European terminology in adult learning for a common language and common understanding and monitoring of the sector (NRDC, 2010a, 2010b, 2010c). During this research project, a glossary of key definitions relevant to the adult learning sector has been developed, and a set of core data for better monitoring of the sector has been proposed. The project covered all 27 EU member states, plus six more countries. In total, 67 terms (listed alphabetically in English) were defined in the Level 1 glossary (NRDC, 2010b) and translated into 27 languages. The terms included in the Level 2 glossary (NRDC, 2010c) were organised conceptually within the framework used to structure findings from the data sources strand of the study. The study provided a pragmatic definition of an adult for the EU purposes, based on the fact that 16 is the age of maturity in some EU countries; namely, an adult is 'any person aged 16 years or older who has left the initial education and training system' (NRDC, 2010b, p. 14). According to the Guidelines for the Development of Education for 2014-2020 (MoES, 2014), in Latvia, youngsters are people aged 13-25; therefore, anyone who is 26 years old or older is considered to be an adult in Latvia. According to the Lifelong Learning Policy for 2007-2013 (Cabinet of Ministers of the Republic of Latvia, 2007), the term 'adult' means a person aged 15 and older (i.e., after the age of acquiring compulsory education), who after a break continues general or professional education (formal, non-formal, informal). Thus, any person older than 15 who 
has interrupted and later continues general or vocational education is considered to be an adult in the frame of lifelong learning policy in Latvia. It can be concluded that in Latvia a unified system of understanding the term 'adult' in the sense of biological age does not exist. In this paper, the term 'young adult' will be used to refer to the age of 15-29.

Young adults are in a transition stage between adolescence and adulthood. According to Baxter Magolda's theory, analysed by Jordan et al. (2008) as well as by Criu and Ceobanu (2013), young adults can quickly learn large amounts of material and easily memorise and retain knowledge; therefore, the efficiency of learning is high. Furthermore, their knowledge is transitional (facilitates the understanding and application of the knowledge acquired), independent (promotes the development of personal perspectives), and contextual (enables collaborative and situational learning). Considering the above-mentioned approach to analysing adult education (Falasca, 2011), the concept of the current paper supports such kind of learning, viewing adult education as a contributor to developing people's career and as a means to enhance their life quality.

\section{Legislative Framework}

Adult learning means 'the entire range of formal, non-formal and informal learning activities which are undertaken by adults after a break since leaving initial education and training and which result in the acquisition of new knowledge and skills. This includes university-level or higher education undertaken after a break (other than for deferred entry) since leaving initial education and training.' (NRDC, 2010b, p. 15) According to the Education Law adopted by the Saeima of the Republic of Latvia on 29 October 1998, adult learning is a multiform process ensuring the development of personality and ability to compete in the labour market during one's lifetime. According to the Lifelong Learning Policy for 2007-2013 (Cabinet of Ministers of the Republic of Latvia, 2007), adult learning is formal, non-formal and informal learning that ensures personal development, social integration, civil participation and competitiveness in labour market during the whole life. Furthermore, as it is mentioned in EAEA report (2011, p. 5), 'the main goal of adult learning in Latvia is to provide individuals with the opportunity to obtain or complement to the existing learning based on needs and interests, irrespective of age, sex and previous education with an emphasis on up-skilling or re-skilling.

Adult learning in Latvia as a part of the lifelong learning process includes all the types of formal (within the general, vocational and higher education), non-formal and informal education including further and interest-related education, professional upgrading, and in-service training. In 2007, the 
Government of Latvia did not adopt the proposed Law on Adult Education. Instead, it was decided that Latvia will integrate adult learning within the $E d u$ cation Law (The Saeima of the Republic of Latvia, 1998), the Vocational Education Law (The Saeima of the Republic of Latvia, 1999), the Law on Institutions of Higher Education (The Saeima of the Republic of Latvia, 1995) and the Regulations of the Cabinet of Ministers. The National Development Plan of Latvia for 2014-2020 (MoES, 2012, p. 45) adopted by the Saeima on 20 December, 2012 within the priority 'Human Securitability' (a form of resilience), which aims at developing 'adult education promoting an increase in labour productivity in accordance with the needs of the labour market'.

Adult education in Latvia is administered at three levels - national, municipal and institutional. The main challenges of adult education are as follows: increasing the participation rate in adult learning, validating the non-formal and informal learning outcomes, increasing mobility opportunities for learners, matching the education with the labour market needs, creating opportunities for promoting and developing basic skills, reducing the dropout rate, and enhancing second chance education opportunities. Within the Latvian framework of the formal educational system, adult education extends over general education (basic and secondary), vocational education and training (VET), post-secondary education (further vocational training) and higher education. There is a wide range of non-formal adult education opportunities, provided by the state, local government and private education institutions. Adult education is available in a number of forms, including full-time, extramural education; extramural - distance learning (also for general education), or self-directed education (EAEA, 2011). As can be seen, the main challenges of Latvia coincide with those in many other countries and their solution is crucial to reaching the Sustainable Development Goal for Education as indicated in Agenda 2030 (UNESCO, 2016a) on inclusive and equitable quality education and lifelong learning opportunities for all in order to eradicate poverty and ensure sustainable development of the society.

\section{The Specifics of Adult Learning}

Adult learning has its specifics. Knowles, Holton and Swanson (2011) discussed new perspectives on andragogy emerging from the research and theory in different disciplines taking into an account the 'core andragogical principles' such as self-directed learning, problem solving, readiness to learn, prior experiences of the learner, the learner's need to know, motivation to learn, and orientation to learning. 'Andragogical principles must be sufficiently applied for adult learners [...] in order to create and maintain experiences that are 
inviting, engaging, motivating, and personally rewarding' (Finn, 2011, p. 39). As suggested by Foote (2015), adult education should liberate adult learners from passive, mindless, and uncritical acceptance of experience and how experience shapes knowledge. She also stressed that 'learning to re-evaluate and re-story prior learning experiences can lead adults to make sense of their experience and find a new sense of identity' (Foote, 2015, p. 84). Applying and transferring knowledge is one of the ultimate learning goals in adult education (Hung, 2013). Murray and Mitchell (2013) argue that the adult learning environment can both enhance and limit the engagement and re-engagement of young adults in education. An environment that promotes adult learning has to encompass freedom, autonomy and flexibility, positive and respectful adult learner-adult teacher relationships, 'in which young people feel that they are "treated like an adult"' (Murray \& Mitchell, 2013, p. 114). Videos, competitions, interactive tools via digital and/or traditional platforms may support young adults' learning by simulating lifelike situations (OECD, 2017b, p. 38). Adult learning has to be transformative (Foote, 2015; Mirci \& Hensley, 2010; Nohl, 2015, etc.) to engage young adult learners in a lifelong process of personal construction and transformation.

\section{Entrepreneurship for Eliminating Youth Unemployment}

The theoretical framework of the research is based on the existing theories and empirical findings in the field of youth learning, unemployment, entrepreneurship, and employability:

- Youth unemployment (Council of the European Union, 2014; Grinevica \& Kovalevs, 2015; Grineviča \& Rivža, 2015; Grineviča, Rivža, \& Koval̦evs, 2015; OECD, 2015a, 2016, 2017a; Pīgozne, 2014; Starineca \& Voronchuk, 2015);

- The definitions of entrepreneurship (Chell, 2007; Council of the European Union, 2018; Flora, 2006; Gibb, 2007; Neck \& Greene, 2011; Oganisjana, 2010, 2012);

- $\quad$ Entrepreneurship as a solution to tackle youth unemployment (Council of the European Union, 2014; OECD, 2015a, 2017a, 2017b; Rastrigina, 2010; Wochowska, 2015);

- $\quad$ The role of formal, non-formal, and informal learning in promoting youth entrepreneurship and employability (Council of the European Union, 2014; European Commission, 2014; Eurofound, 2015; Oganisjana, 2010, 2012; Pīgozne, 2014; SALTO-YOUTH, 2016; UNESCO, 2016a; Wochowska, 2015, etc.). 
The problem of youth unemployment in the European Union is not new, but in December 2013 youth unemployment rates were historically high, at $23.2 \%$ in the EU-28 and $23.8 \%$ in the euro area (Council of the European Union, 2014, p. 1). Although the situation has improved recently, youth unemployment rates remain high: $14.2 \%$ in the EU-28 and $15.8 \%$ in the euro area (Eurostat Statistics, 2019). Youth unemployment is also a significant social issue in Latvia (Grinevica \& Kovalevs, 2015; Grineviča \& Rivža, 2015; Grineviča et al., 2015; OECD, 2015a; Pīgozne, 2014; Starineca \& Voronchuk, 2015). OECD Indicators on Education (OECD, 2016a) indicate that educational attainment significantly increases the employment rate. Limited employment possibilities and the threat of unemployment, job dissatisfaction or loss of paid jobs are the main 'push factors' which can facilitate youth engagement in entrepreneurial activity (Rastrigina, 2010). Entrepreneurship could be perceived as one of the solutions to tackle youth unemployment (Council of the European Union, 2014; OECD, 2015a, 2017a, 2017b; Wochowska, 2015).

The entrepreneurship competence is one of the updated eight key competences defined by the EU (Council of the European Union, 2018). It refers to an individual's capacity to act upon opportunities and ideas, and transform them into values for others. Creativity, critical thinking, problem solving, initiative, collaboration are significant therein. (Council of the European Union, 2018, p. C189/11).

In academic literature, entrepreneurship has been defined as a process (Neck \& Greene, 2011); method (Neck \& Greene, 2011); an individual's different qualities, skills, abilities, and traits (Flora, 2006); behaviour (Chell, 2007); and a combination of individual's behaviour and different qualities (Gibb, 2007). Oganisjana (2010) claims that entrepreneurship is a multi-component and multi-category dynamic system and it should be considered holistically. She defined entrepreneurship as 'a dynamic system of individual's causally interrelated personality traits, motivation, cognition, needs, emotions, abilities, learning, skills and behaviour, on the basis of which an individual or a group of individuals interact with the context for identifying, generating and realizing opportunities into new values' (Oganisjana, 2010, p. 54). In the current research, the definition of entrepreneurship by Oganisjana (ibid.) is adopted.

The critical role of formal, non-formal and informal learning in promoting youth entrepreneurship and employability is widely recognised (Council of the European Union, 2014; European Commission, 2014; OECD, 2017a, 2017b; Pìgozne, 2014; SALTO-YOUTH, 2016; Wochowska, 2015). The Council of the European Union (2014, p. 4) has invited the member states 'to recognise the importance of entrepreneurial education from an early age and highlight the role of non-formal and informal learning to ensure a holistic approach to the 
personal development of young people and facilitate their successful integration into the labour market'. Literacy proficiency, including a highly developed sense of entrepreneurship, education and employment are interrelated. Moreover, 'proficiency plays an important and independent role as a determinant of success in the labour market' (OECD, 2016b, p. 122).

The three main challenges of supporting youth entrepreneurship and self-employment in Europe are fostering a more entrepreneurial mindset, attitudes and culture; providing information, advice, coaching and mentoring; removing practical barriers and easing access to credit (Eurofound, 2015, p. 2). The support provided to young adults in Latvia is targeted at eliminating youth unemployment and favouring the development of their entrepreneurship. Some of the initiatives available turn to be more efficient than others. Therefore, this paper will focus on analysing them from the aspect of young adults and education providers.

\section{Method}

\section{Research Purpose and Objectives}

The purpose of the current paper is to identify the most/least-efficient non-formal and informal learning methods, forms, and initiatives to promote youth entrepreneurship and employability in Latvia as well as to show the relationship between the profile of young adults and their opinion on these methods, forms, and initiatives.

The objectives of the paper:

1. To analyse the terminology issues and the legislative framework of Latvia concerning adult education in order to explain the research context;

2. To analyse the findings obtained in the given exploratory research and, based on them and the literature review done, provide implications concerning the promotion of young adults' entrepreneurship in the country.

\section{The research questions}

The research questions of the study are as follows:

1. Which are the most and least efficient non-formal and informal learning methods, forms, and initiatives to promote youth entrepreneurship and employability in Latvia?

2. Is there any relationship between the opinion of young adults concerning the methods, forms, and initiatives mentioned above and their gender, education level, employment status and non-formal and informal learning experience? 


\section{Procedure and Research Methods}

To answer the research questions, exploratory research applying a webbased survey as a tool for data collection and a mixed-method approach (quantitative and qualitative) for data analysis was conducted (Collis \& Hussey, 2009). The exploratory research was selected as it allows studying the trends and patterns of behaviour of young adults, whereas the mixed-method approach for data analysis provides more opportunities for data analysis and ensured more valid and reliable findings and conclusions (Collis \& Hussey, 2009).

\section{Instruments}

The online survey containing a 4-point Likert scale ranking, category and open questions was created based on the theory on developing youth entrepreneurship (Oganisjana, 2010, 2012), as well as the analysis of the measures and opportunities available for adult learners in the country (SEA, 2016). The Google Docs platform was used for the survey. In the survey the respondents reflected on their previous learning experience focusing on formal, non-formal, and informal learning methods and forms, skills acquired, and their compliance with the labour market needs. In the open questions, they had to express their opinions on the ways to increase education quality, write their success story to getting a job, their extracurricular experience, tell why exactly they were successful - which skills, qualifications, initiatives, etc. had helped them.

Quantitative data were analysed using SPSS software (frequencies, crosstabs, hierarchical cluster analysis, etc.) (Arhipova \& Bāliṇa, 2003) and qualitative data were analysed using AQUAD software (frequencies, linkages, implicants) (Huber \& Gürtler, 2013).

\section{Sample}

The survey was administered to the non-random handpicked (purposive) sample comprising 81 most experienced institutional representatives providing adult education services (see Table 1) and snowball sampling of 405 young adults aged 15-29 (see Table 2) involved in learning (Walliman, 2016). The handpicked sampling allows surveying individuals whose role and experiences provide relevant information in the field (O'Leary, 2010, p. 172) and the snowball sampling helped to increase the sample size of the young adults. 
Table 1

The profile of the representatives of the institutions

\begin{tabular}{ll}
\hline Category & Profile \\
\hline Institution type & 5 universities/colleges; 14 general education institutions; 14 evening (shift) \\
& schools; 7 VETs; 10 private educational centres; 14 municipality organisa- \\
& tions; 9 cultural institutions; 5 NGOs; 2 enterprises; 1 foundation \\
\hline
\end{tabular}

Table 2

The profile of the young adults

\begin{tabular}{ll}
\hline Category & Profile \\
\hline Gender & 326 female; 79 male \\
\hline Education level & $\begin{array}{l}61 \text { - lower secondary education; } 109 \text { - upper secondary education; } \\
50 \text { - vocational education; } 185 \text { - higher education }\end{array}$ \\
\hline $\begin{array}{l}\text { Non-formal and } \\
\text { informal learning } \\
\text { experience }\end{array}$ & $\begin{array}{l}\text { 111 have non-formal and informal learning experience; } \\
\text { Employment status not have such experience }\end{array}$ \\
\hline $\begin{array}{l}\text { 172 employees; } 31 \text { entrepreneurs; } 44 \text { self-employed; } 60 \text { unemployed; } \\
\text { schools, vocational schools, evening (shift) schools }\end{array}$ \\
\hline
\end{tabular}

\section{Findings and Discussion}

The results of the web-based survey indicated that the respondents recognised internship in a company or institution (49.38\%), projects $(40.78 \%)$, other persons' experience and success stories (39.55\%), and training enterprises (18.91\%) as the most efficient non-formal and informal learning methods, forms, and initiatives to promote youth entrepreneurship and employability in Latvia. Such results may be explained by the fact that in Latvia employers increasingly require employees with work experience. The largest Internet job vacancy portal in Latvia CV Online shows that 801 job advertisements out of 2298 vacancies available on August 8, 2017, required previous work experience in the field (CV Online, 2017). Consequently, having an internship in a company or institution, training enterprises and participating in projects are the ways to gain initial experience.

This significant finding confirms that the country is on the right track offering these initiatives. Moreover, as emphasised in 'OECD Skills Outlook 2017 ' (OECD, 2017a, p. 31) a strong work-based learning component that is important for enhancing youth entrepreneurship may be ensured by fostering cooperation between education providers and the private sector, i.e., industry. 
The quantitative data obtained by collecting responses to closed-ended questions are in line with the qualitative data obtained by analysing the answers to open-ended questions. In their success stories on getting a job, young people stressed the importance of cooperation with employers to organise educational activities, field trips as well as internships, projects, meetings with entrepreneurs to learn their experience. The respondents also appreciated the importance of such kind of cooperation to gain the first work experience that facilitated their involvement in entrepreneurship, improved their professional self-determination, competitiveness, career development and quality of life:

At the end of my studies, it was necessary to undergo the internship, during which I have proven myself as a good employee. With the internship supervisor's recommendation letter, I applied for the selected post. So, I got the job.

At first, I worked as a volunteer, helping to translate during the conference, I was noticed and invited to work full-time in this organisation.

I went to pre-school to work as a cleaner and began to show my good qualities. When the teacher fell ill, there was nobody who could work with children, I had an opportunity and showed myself. I was offered to work as a nanny and then as a music teacher. Currently, I manage my own day centre.

I was involved in the activity 'Workplace for a youngster' proposed by the State Employment Agency four years ago. During my internship, I proved myself as a potential employee, created contacts with customers, and after the internship, I got a job at another company.

As the examples above demonstrate, pro-active behaviour on the part of young people has resulted in obtaining employment, which again underscores the significance of developing youth entrepreneurship skills. According to the representatives of institutions, youth involvement in the labour market is perceived as an added value to internships:

After internships, the best students become employees of the company.

After qualifying for an internship in a company or institution, the student becomes an employee. 
Thus, as a result of successful collaboration with employers, the students found a full-time job.

Mentoring (6.63\%), business incubators (5.89\%), coaching $(5.40 \%)$, individual work/action plan - the roadmap for the youngsters $(2.70 \%)$, business clubs (1.19\%), and business start-up funds/grants (1.96\%) were considered the least efficient non-formal and informal learning methods, forms, and initiatives to promote youth entrepreneurship and employability in Latvia.

These results contradict those obtained in the recent OECD studies on skills (OECD, 2016b, p. 18; OECD, 2017a, p. 132) according to which mentoring, co-working spaces, and incubation facilities have been highly valued as well as both students and staff require them. This means that apparently these initiatives have not been sufficiently promoted in Latvia.

A statistically significant relationship was discovered between respondents' opinion and their gender, education level, employment status and nonformal and informal learning experience. For instance, according to the results of cross-tabulation (Chi-Square): $\chi^{2}=6.347$ (1); $\mathrm{p}=.012$, females participated in the projects more often than the males: $44.2 \%$ of females vs. $27.8 \%$ of males.

It has to be emphasized that this is a general trend in the country. The data by the State Employment Agency (SEA, 2017) point to a similar situation. In May 2017, out of all unemployed, 12,471 or $18.2 \%$ (7,312 female, 5,159 male) were aged 15-29. As to their education, most of the unemployed had vocational education which points to a gap between the supply and the demand. The second group was low qualified. The initiative Measures to Increase Competitiveness has been the most popular initiative targeted at unemployed people. On the third position is the initiative Measures of the Youth Guarantee that comprises nine different branches. Several of them also involve participation in projects, for example, Workshops for the Youth (SEA, 2016).

According to the results of cross-tabulation, young adults having vocational education more often used internship in a company or institution $\left(\chi^{2}=38.618\right.$ (3); $\left.\mathrm{p}=.000\right)$ compared to those with lower and upper secondary education. This might be explained by the fact that VET graduates are familiar with practical training as the internship is a significant component of any VET study programme.

Young adults having obtained higher education more often used mentoring than those with vocational education $\operatorname{did}\left(\chi^{2}=9.921(3) ; \mathrm{p}=.019\right)$. Moreover, compared to the young adults with lower secondary education they more often used individual counselling $\left(\chi^{2}=8.849\right.$ (3); $\left.\mathrm{p}=.031\right)$, other persons' experience and success stories $\left(\chi^{2}=17.353(3) ; p=.001\right)$, and meetings with the experts from different fields $\left(\chi^{2}=12.540(3) ; \mathrm{p}=.006\right)$. However, it has to be admitted 
that mentoring has not been valued much, in fact, only $6.633 \%$ have used it. Drawing parallels with the studies conducted by the State Employment Agency (SEA, 2016) most initiatives include counselling (individual or group consultations), but the job-seekers give preference to various courses. Concerning other persons' experience and success stories, as well as meeting with experts, tertiary level students have direct contact with them in lectures and extracurricular activities organised at their universities. Their positive impact is also stressed in an OECD study on skills (OECD, 2017a, p. 31).

Next, the results of cross-tabulation showing the preferences of the selfemployed young adults, entrepreneurs and employees are summarised in Table 3. These data confirm the relationship between the young adults' opinion and their employment status.

Table 3

Significant relationship between young adults' opinion and employment status

\begin{tabular}{|c|c|c|c|}
\hline $\begin{array}{l}\text { Learning methods, forms, } \\
\text { and initiatives }\end{array}$ & $\begin{array}{l}\text { Results of cross-tabulation } \\
\text { (Chi-Square) }\end{array}$ & $\begin{array}{l}\text { More often } \\
\text { preferred by }\end{array}$ & $\begin{array}{l}\text { Less often } \\
\text { preferred by }\end{array}$ \\
\hline $\begin{array}{l}\text { Internship in a company or } \\
\text { institution }\end{array}$ & $\begin{array}{l}\chi^{2}=28.787(3) \\
p=.044\end{array}$ & Self-employed & Students \\
\hline Work camps & $\begin{array}{l}\chi^{2}=11.212(3) \\
p=.004\end{array}$ & Self-employed & Unemployed \\
\hline Coaching & $\begin{array}{l}\chi^{2}=12.052(3) \\
p=.034\end{array}$ & Self-employed & Unemployed \\
\hline $\begin{array}{l}\text { Other persons' experience } \\
\text { and success stories }\end{array}$ & $\begin{array}{l}\chi^{2}=17.212(3) \\
p=.004\end{array}$ & Self-employed & Students \\
\hline Business forums & $\begin{array}{l}\chi^{2}=11.921(3) \\
p=.036\end{array}$ & Self-employed & Unemployed \\
\hline $\begin{array}{l}\text { Business start-up funds/ } \\
\text { grants }\end{array}$ & $\begin{array}{l}\chi^{2}=26.271(3) \\
p=.000\end{array}$ & Self-employed & Employees \\
\hline Individual counselling & $\begin{array}{l}\chi^{2}=18.582(3) \\
p=.002\end{array}$ & Entrepreneurs & Students \\
\hline Projects & $\begin{array}{l}\chi^{2}=13.073(3) \\
p=.023\end{array}$ & Entrepreneurs & Unemployed \\
\hline $\begin{array}{l}\text { Meetings with the experts } \\
\text { from different fields }\end{array}$ & $\begin{array}{l}\chi^{2}=11.658(3) \\
p=.040\end{array}$ & Entrepreneurs & Unemployed \\
\hline $\begin{array}{l}\text { Individual work/action } \\
\text { plan - the roadmap for the } \\
\text { youngsters }\end{array}$ & $\begin{array}{l}\chi^{2}=12.121(3) \\
p=.033\end{array}$ & Employees & Unemployed \\
\hline
\end{tabular}

The findings indicate that young adults involved in some form of entrepreneurship (self-employed, entrepreneurs) are more inclined towards using opportunities of self-development from hands-on-experience in businessrelated activities, e.g., internship, business start-ups, various projects, etc. 
compared to other respondents, which might be explained by their readiness to act and risk, use every opportunity; in other words, they might be considered as more-pro-active.

In turn, according to the theory, it is pro-activity that enhances their competitiveness (Bakker, Tims, \& Derks, 2012; Bertolino, Truxillo, \& Fraccaroli, 2011; Dikkers, Jansen, de Lange, Vinkenburg, \& Kooij, 2010; Parker, Bindl, \& Strauss, 2010). Pro-active people take the initiative in acting, anticipating and preventing problems, improving the existing situation, using opportunities, creating new value and engaging in learning (Dikkers et al., 2010, p. 61; Parker et al., 2010, p. 827). Pro-activity draws innovation, change and moves society a step forward. Entrepreneurship, alongside other possible activities, such as volunteering, participating in social campaigns, giving a hand to those in need, etc., is a means to developing one's pro-activity.

The results of cross-tabulation also confirm a significant relationship between the opinions of young adults and their non-formal and informal learning experience (see Table 4 ).

Table 4

Significant relationship between the opinion of young adults and their nonformal and informal learning experience

\begin{tabular}{llll}
\hline $\begin{array}{l}\text { Learning methods, forms, } \\
\text { and initiatives }\end{array}$ & $\begin{array}{l}\text { Results of cross-tabulation } \\
\text { (Chi-Square) }\end{array}$ & $\begin{array}{l}\text { More often were } \\
\text { involved }\end{array}$ & $\begin{array}{l}\text { Less often were } \\
\text { involved }\end{array}$ \\
\hline $\begin{array}{l}\text { Internship in a company or } \\
\text { institution }\end{array}$ & $\begin{array}{l}\chi^{2}=16.828(1) \\
\mathrm{p}=.000\end{array}$ & $\begin{array}{l}\text { Experienced } \\
\text { young adults }\end{array}$ & $\begin{array}{l}\text { Non-experi- } \\
\text { enced young } \\
\text { adults }\end{array}$ \\
\hline Volunteering & $\begin{array}{l}\chi^{2}=7.259(3) \\
\mathrm{p}=.007\end{array}$ & $\begin{array}{l}\text { Experienced } \\
\text { young adults }\end{array}$ & $\begin{array}{l}\text { Non-experi- } \\
\text { enced young } \\
\text { adults }\end{array}$ \\
\hline Individual counselling & $\begin{array}{l}\chi^{2}=9.943(1) \\
\mathrm{p}=.007\end{array}$ & $\begin{array}{l}\text { Experienced } \\
\text { young adults }\end{array}$ & $\begin{array}{l}\text { Non-experi- } \\
\text { enced young } \\
\text { adults }\end{array}$ \\
\hline Workshops for youngsters & $\begin{array}{l}\chi^{2}=4.221(1) \\
\mathrm{p}=.040\end{array}$ & $\begin{array}{l}\text { Experienced } \\
\text { young adults }\end{array}$ & $\begin{array}{l}\text { Non-experi- } \\
\text { enced young } \\
\text { adults }\end{array}$ \\
\hline Projects & $\begin{array}{l}\chi^{2}=11.550(1) \\
\mathrm{p}=.001\end{array}$ & $\begin{array}{l}\text { Experienced } \\
\text { young adults }\end{array}$ & $\begin{array}{l}\text { Non-experi- } \\
\text { enced young } \\
\text { adults }\end{array}$ \\
\hline Business clubs & $\begin{array}{l}\chi^{2}=9.372(1) \\
\mathrm{p}=.002\end{array}$ & $\begin{array}{l}\text { Experienced } \\
\text { young adults }\end{array}$ & $\begin{array}{l}\text { Non-experi- } \\
\text { enced young } \\
\text { adults }\end{array}$ \\
\hline
\end{tabular}

These findings increasingly stress the significance of education, training and experience, which are significant preconditions for entrepreneurship. 
Therefore, it is essential to increase youth motivation to engage in any form of learning, as any learning may be beneficial both to learners and society.

The results of hierarchical cluster analysis applying SPSS software indicate a more likely probability of promoting youth entrepreneurship and selfemployment for the young adults having non-formal and informal learning experience. These results are in line with the results of the qualitative data analysed using AQUAD software. The main regularity identified during both qualitative and quantitative data analysis confirms that the young adults' involvement in the labour market is determined by their non-formal and informal learning experience. This again emphasises the role of lifelong learning, the necessity to 'promote flexible learning pathways in both formal and non-formal settings' (UNESCO, 2016a, p. 44), which is mentioned as one of the indicative strategies to attain Target 4 of the sustainable development of Education 2030. Moreover, the research highlighted certain initiatives that the young adults found more appealing than others. It is essential to use those success stories, such as using extra-curricular activities, also stressed by OECD (2015b, pp. 20-21) to enhance youth entrepreneurship.

\section{Concluding Remarks}

In Latvia, adult education is considered as a part of lifelong learning, and it is perceived as a diverse process offering personal development and the capacity to cope in the labour market throughout life, consequently ensuring adults' career development and contributing to their quality of life. Youth learning is understood as a part of adult learning, and it is defined as an early stage of adult learning. Adult education is regulated by the national legislation and is administered at three levels - national, municipal and institutional.

Young adults stressed the importance of cooperation with employers to organise educational activities, field trips, as well as internships, projects, and meetings with entrepreneurs to learn about their experience. Furthermore, the respondents appreciated the importance of cooperation to gain the first work experience, thus facilitating their involvement in entrepreneurship, improving their professional self-determination, competitiveness, career development, and quality of life in general.

According to the current research, the most efficient non-formal and informal learning methods, forms, and initiatives to promote youth entrepreneurship and employability in Latvia are internships in a company or institution, projects, other persons' experience and success stories, and training enterprises. Whereas, the least efficient ones are mentoring, business incubators, 
coaching, individual work/action plan for young people, business clubs, and business start-up funds/grants.

The opinion of young adults on all aspects of non-formal and informal learning methods, forms, and initiatives depends on their profile (gender, education level, employment status, learning experience).

The means of social pedagogical support, such as cooperation, encouragement and confidence contribute to the involvement of young adults in the labour market. A positive trend in Latvia has been observed - employers' participation in various initiatives and activities: in education policy-making through cooperation to elaborate education programs based on labour market demand and supply; in the organisation of the study process; in the modernisation of educational resources by providing financial support; in the evaluation of education quality, which enables balancing the proportion of theory and practice in the study process, as well as optimising, consolidating and using resources rationally.

\section{Implications for Further Studies}

The current research is connected with the following priorities set in national and international policy documents: youth as a priority target group in labour market policy measures; education as a means of combating poverty and social exclusion; promoting youth entrepreneurship and employment; developing the system of recognition of non-formal and informal learning in the EU in order to ensure all people an opportunity of recognising their knowledge, skills and competences acquired irrespective of mode of learning and environment; promoting knowledge partnerships and strengthening links and a dialogue between formal, non-formal and informal education providers. The added value of the current research is the opportunities identified for promoting young adults' entrepreneurship and employment using the initiatives and measures provided in non-formal and informal education in the post-crisis period as well as conducting comparative research, analysing their dynamics and participating in the monitoring of the implementation of policy planning documents long-term. In the future, it would be essential to study the feedback from employers evaluating the quality of the young adults' knowledge and competences acquired, as well as research the various new initiatives offered in the country and their compatibility with the labour market needs. 


\section{References}

Arhipova, I., \& Bāliņa, S. (2003). Statistika ekonomikā [Statistics in economics]. Rīga: Datorzinību centrs.

Bakker, A. B., Tims, M., \& Derks, D. (2012). Proactive personality and job performance: The role of job crafting and work engagement. Human Relations, 65(10), 1359-1378.

Bertolino, M., Truxillo, D. M., \& Fraccaroli, F. (2011). Age as moderator of the relationship of proactive personality with training motivation, perceived career development from training, and training behavioral intentions. Journal of Organizational Behavior, 32(2), 248-263.

Buchert, L. (2014). Learning needs and life skills for youth: An introduction. International Review of Education, 60(2), 163-176.

Cabinet of Ministers of the Republic of Latvia. (2007). Lifelong learning policy for 2007-2013.

December 9, 2009 amendments incorporated. Retrieved from http://asemlllhub.org/fileadmin/www. asem.au.dk/LLL_Policies/Latvia_-_Ministry_of_Education_and_Science._Basic_guidelines_of_ lifelong_learning_policy_for_2007_-_2013.pdf

Cedefop. (2015). Encouraging adult learning: Despite improvements, adult learning still needs to become more attractive, inclusive, accessible and flexible. Briefing Notes, 9099, August 2015.

Chell, E. (2007). Social enterprise and entrepreneurship: Towards a convergent theory of the entrepreneurial process. International Small Business Journal, 25(1), 5-26.

Collis, J., \& Hussey, R. (2009). Business research. Basingstoke, UK: Palgrave Macmillan. Council of the European Union. (2014). Conclusions on promoting youth entrepreneurship to foster social inclusion of young people. Retrieved from https://www.consilium.europa.eu/ media/28269/142702.pdf

Council of the European Union. (2018). Council Recommendation of 22 May 2018 on Key competences for lifelong learning. (2018/C 189/01). Official Journal of the European Union. Retrieved from https:// eur-lex.europa.eu/legal-content/EN/TXT/PDF/?uri=CELEX:32018Ho604(01)\&from=EN Criu, R., \& Ceobanu, C. (2013). E-learning implications for adult learning. Turkish Online Journal of Distance Education-TOJDE, 14(2), 56-65.

CV Online. (2017). Portal of job vacancies in Latvia. Retrieved from http://www.cv.lv/darbasludinajumi/q-darba\%2opieredze

Dikkers, J. S. E., Jansen, P. G. W., de Lange, A. H., Vinkenburg, C. J., \& Kooij, T. A. M. (2010). Proactivity, job characteristics, and engagement: a longitudinal study. Career Development International, 15(1), 59-77.

EAEA (European Association for the Education of Adults). (2011). Country report on adult education in Latvia. Retrieved from https://eaea.org/wp-content/uploads/2018/o1/latvia_country-report-onadult-education-in-latvia.pdf EAEA (European Association for the Education of Adults). (2014). Adult education in Europe 2014 A civil society view. Retrieved from https://eaea.org/wp-content/uploads/2018/o6/ae-in-europe-2014_ complete.pdf 
Eurofound. (2015). Youth entrepreneurship in Europe: Values, attitudes, policies. Luxembourg: Publications Office of the European Union. Retrieved from https://eaea.org/wp-content/ uploads/2018/o6/Country-reports_Full-Report-09-12-2016_small.pdf European Commission/EACEA/Eurydice. (2015). Adult education and training in Europe: Widening access to learning opportunities. Eurydice Report. Luxembourg: Publications Office of the European Union. Retrieved from https://www.erasmusplus.sk/uploads/publikacie/2015_AEducation_ LOAccess_Eurydice_Comparative_Report_en.pdf European Commission. (2014). Developing the creative and innovative potential of young people through non-formal learning in ways that are relevant to employability. Expert Group Report. Retrieved from http://ec.europa.eu/assets/eac/youth/news/2014/documents/report-creativepotential_en.pdf

Eurostat Statistics. (2019). Unemployment statistics. Data up to April 2019. Retrieved from http:// ec.europa.eu/eurostat/statistics-explained/index.php/Unemployment_statistics

Falasca, M. (2011). Barriers to adult learning: Bridging the gap. Australian Journal of Adult Learning, 51(3), 583-590.

Finn, D. (2011). Principles of adult learning: An ESL context. Journal of Adult Education Information Series, 40(1), 34-39.

Flora, C. (2006). Are entrepreneurs born or made? Rural Development News, 28(4), 1-7.

Foote, L. S. (2015). Transformational learning: Reflections of an adult learning story. Adult Learning, 26(2), 84-86.

Gibb, A. A. (2007). Enterprise in education. Educating tomorrow's entrepreneurs. Pentti Mankinen 2007, 1-19. Retrieved from http://www.enorssi.fi/hankkeet/yrittajyyskasvatus/pdf/Gibb.pdf Grinevica, L., \& Kovalevs, R. (2015). Integration of young people into the Latvian labour market. Economics \& Business, 27(1), 64-68.

Grineviča, L., \& Rivža, B. (2015). Legal framework of youth unemployment and entrepreneurship regulation in Latvia. Regional Formation \& Development Studies, 1(15), 56-64.

Grineviča, L., Rivža, B., \& Koval̦evs, R. (2015). Youth social inclusion trends in the Latvian labour market. Socialiniai tyrimai/Social Research, 1(37), 57-66.

Hoskins, B., Janmaat, J. G., \& Villalba, E. (2012). Learning citizenship through social participation outside and inside school: An international, multilevel study of young people's learning of citizenship. British Educational Research Journal, 38(3), 419-446.

Huber, G. L., \& Gürtler, L. (2013). AQUAD 7. Manual: The analysis of qualitative data. Tübingen: Softwarevertrieb Günter Huber. Retrieved from http://www.aquad.de/materials/manual_aquad7/ manual-e.pdf

Hung, W. (2013). Problem-based learning: A learning environment for enhancing learning transfer. New Directions for Adult and Continuing Education, 137, 27-38.

Jordan, A., Carlile, O., \& Stack, A. (2008). Approaches to learning. A guide for teachers. New York, NY: Open University Press. Retrieved from http://www.principals.in/uploads/pdf/ CurriculumDesignPlanning/Jordan_Approaches_to_Learning_0335226701.pdf 
Knipprath, H., \& De Rick, K. (2014). The economic benefits of adult learning to low-qualified young adults: Do participation and qualification decrease the risk of unemployment? Vocations and Learning, $7(1), 101-120$.

Knowles, M. S., Holton, E. F., \& Swanson, R. A. (2011). The adult learner: The definitive classic in adult education and human resource development. Oxford, UK: Elsevier.

Mirci, P. S., \& Hensley, P. A. (2010). Leading for innovative practice: Melding theories of organizational change, adult learning, and conditions of learning. CAPEA Education Leadership and Administration, 22, 9-30.

MoES (The Ministry of Education and Sciences of the Republic of Latvia). (2014). Izglitìibas attīstības pamatnostādnes 2014-2020. gadam [Guidelines for the development of education for 2014-2020].

Retrieved from http://m.likumi.lv/doc.php?id=266406

Murray, S., \& Mitchell, J. (2013). The 'double-edged sword' of the adult learning environment. Australian Journal of Adult Learning, 53(1), 111-128.

Neck, H. M., \& Greene, P. G. (2011). Entrepreneurship education: Known worlds and new frontiers. Journal of Small Business Management, 49(1), 55-70.

Nohl, A. M. (2015). Typical phases of transformative learning: A practice-based model. Adult Education Quarterly, 65(1), 35-49.

NRDC (The National Research and Development Centre for adult literacy and numeracy). (2010a). Final report for: Study on European terminology in adult learning for a common language and common understanding and monitoring of the sector. Retrieved from http://languageforwork.ecml.at/ Portals/48/documents/lfw-web_item-3a_nrdc_european-adult-learning-glossary-rept_en.pdf NRDC (The National Research and Development Centre for adult literacy and numeracy). (2010b). European adult learning glossary, level 1. Study on European terminology in adult learning for a common language and common understanding and monitoring of the sector. Call Number: EAC 11/2008. Retrieved from https://epale.ec.europa.eu/sites/default/files/adultglossary1_en.pdf NRDC (The National Research and Development Centre for adult literacy and numeracy). (2010c). European adult learning glossary, level 2. Study on European terminology in adult learning for a common language and common understanding and monitoring of the sector. Call Number: EAC 11/2008. Retrieved from http://languageforwork.ecml.at/Portals/48/documents/lfw-web_item3c_nrdc_european-adult-learning-glossary2_en.pdf OECD. (2015a). Entrepreneurship support for the unemployed in Latvia. Rapid policy assessments of inclusive entrepreneurship policies and programmes. Report. Paris: OECD Publishing. Retrieved from https://www.oecd.org/latvia/Rapid-Policy-Assesment-Latvia.pdf OECD. (2015b). Investing in youth: Latvia. Paris: OECD Publishing. Retrieved from https://dx.doi. org/10.1787/9789264240407-en OECD. (2016a). Education at a glance 2016: OECD indicators. Paris: OECD Publishing. Retrieved from https://dx.doi.org/10.1787/eag-2016-en OECD. (2016b). Skills matter: Further results from the survey of adult skills. Paris: OECD Publishing. Retrieved from http://dx.doi.org/10.1787/9789264258051-en 
OECD. (2017a). OECD skills outlook 2017: Skills and global value chains. Paris: OECD Publishing.

Retrieved from http://dx.doi.org/10.1787/9789264273351-en

OECD. (2017b). PISA 2015 results (volume IV): Students' financial literacy. Paris: PISA, OECD

Publishing. Retrieved from http://dx.doi.org/10.1787/9789264270282-en

O’Leary, Z. (2010). The essential guide to doing your research project. London, UK: SAGE.

Oganisjana, K. (2010). Studentu uznēmības veicināšana studiju procesā: promocijas darba

kopsavilkums doktora zinātniskā grāda iegūšanai pedagoǵijā [The development of students' enterprise in study process] (Doctoral dissertation). Riga: University of Latvia.

Oganisjana, K. (2012). Uzṇēmējspēja un uzṇēmība [Entrepreneurship and enterprise]. Riga: RaKa.

Parker, S. K., Bindl, U. K., \& Strauss, K. (2010). Making things happen: A model of proactive motivation. Journal of Management, 36(4), 827-856.

Pīgozne, T. (2014). Pieaugušo izglìtības resursi jauniešu bezdarba mazināšanai. Ziņojums „Eiropas programmas īstenošana pieaugušo izglīīibas jomä’ ietvaros (Granta lēmuma numurs 2012-3753/oo1o01) [Adult learning resources to diminish youth unemployment. The report developed within the project 'Implementation of the European agenda for adult learning' (Grant decision No 20123753/o01-001)]. Retrieved from http://www.muzizglitiba.lv/sites/default/files/o6_Pigozne_jauniesubezdarbs.pdf

Rastrigina, O. (2010). Global entrepreneurship monitor: 2008 Latvia report. Riga: Stockholm School of Economics in Riga.

SALTO-YOUTH. (2016). Recognition of youth work and of non-formal and informal learning within youth work: Current European developments. Report. Retrieved from https://www.salto-youth.net/ downloads/4-17-3335/5\%20Overview\%20of\%2orecognition\%2opolicy\%2odevelopments\%2oApril\%2O 2016.pdf

SEA (State Employment Agency). (2016). Training and employment opportunities. The webpage of the State Employment Agency. Retrieved from https:/epale.ec.europa.eu/sites/default/files/ adultglossary1_en.pdf

SEA (State Employment Agency). (2017). An overview of the unemployment situation in the country in May 2017. Retrieved from http://nva.gov.lv/docs/31_595f5005eaaaa3.21582742.pdf Starineca, O., \& Voronchuk. I. (2015). Peculiarities of young specialists on labour market: Case of Latvia. Entrepreneurship and Sustainability Issues, 2(4), 198-208.

The Saeima of the Republic of Latvia. (1995). Augstskolu likums [Law on Institutions of Higher Education. Approved by a decision of the Saeima on 2 November 1995]. Retrieved from http:// likumi.lv/doc.php?id=37967

The Saeima of the Republic of Latvia. (1998). Izglitīibas likums [Education Law. Approved by a decision of the Saeima on 29 October 1998] Retrieved from http://likumi.lv/doc.php?id=50759 The Saeima of the Republic of Latvia. (1999). Profesionālās izglìtības likums [Vocational Education Law. Approved by a decision of the Saeima on 10 June 1999]. Retrieved from ttps://likumi.lv/doc. php?id=20244

UNESCO. (2016a). Education 2030. Incheon declaration and framework for action for the 
implementation of sustainable development goal 4: Ensure inclusive and equitable quality education and promote lifelong learning opportunities for all. Retrieved from http://uis.unesco.org/sites/default/ files/documents/education-2030-incheon-framework-for-action-implementation-of-sdg4-2016en_2.pdf

UNESCO. (2016b). Recommendation on adult learning and education 2015. ED-2016/

WS/29. UNESCO Institute for Lifelong Learning. Retrieved from http://unesdoc.unesco.org/ images/oo24/002451/245179e.pdf

Walliman, N. (2016). Social research methods. London, UK: SAGE Publications.

Wochowska, M. (2015). Non-formal learning and the acquisition of skills - How does the EU support youth employment? Comparative Economic Research, 18(2), 161-179.

\section{Biographical note}

Tamara Pigozne, Dr.paed., is a senior researcher at the Scientific Institute of Pedagogy of the Faculty of Education, Psychology and Art of the University of Latvia. Her PhD Thesis was devoted to the issues of inclusive education. Currently her scientific interests encompass STEM teaching and learning, character education, e-learning, inclusive education, adult education, stress management, neuropedagogy and neuropsychology.

INETA LUKA, Dr.paed., is a professor and the head of the Language Department of Turiba University, Latvia, an expert in pedagogy and education management of the Latvian Council of Science, a member of Asia-Europe Meeting (ASEM) Education and Research Hub for Lifelong Learning Research Network 4 on Lifelong Learning Strategies.

Svetlana Surikova, Dr.paed., is a senior researcher at the Scientific Institute of Pedagogy of the Faculty of Education, Psychology and Art of the University of Latvia. Her scientific interests are related to the research of professionalization of adult educators, effectiveness and quality assurance in adult and continuing education as well as interaction between social innovation and education, challenges faced to the promotion of social innovation from the perspective of education. 